\title{
Pokora u ranokršćanskome razdoblju s posebnim osvrtom na svetoga Ambrozija
}

\author{
Drago TUKARA*
}

UDK: 27-788-543.7 Ambrosius, sanctus • Pregledni članak Primljeno: 11. listopada 2016. • Prihvaćeno: 27. veljače 2017.

Sažetak: Autor članak dijeli u dva dijela. U prvom dijelu obrađuje temu pokore u njezinu povijesnom razvoju od samih početaka Crkve pa do kraja petoga stoljeća. U razmatranje je uzet niz društvenih zbivanja na pozornici ondašnjega vremena koji će utjecati na antropološki i teološki vid pokore. Svijest o prisutnosti nastaloga grijeha $u$ vjerničkom životu nakon krštenja sve će više nukati Crkvu na traženje rješenja toga problema. Pronalazak odgovora za pitanje $\gg$ novonastaloga $\ll$ grijeha Crkva vidi u sve tješnjoj suradnji sa Svetim pismom $i$ tradicijom. Oni su pravi izvor Božjega milosrała, oproštenja i spasenja koji se postižu kroz put sakramenta pokore, a on je potreban i obvezan.

${ }^{*}$ Doc. dr. sc. Drago

Tukara, Katolički bogoslovni fakultet u Đakovu Sveučilišta J. J. Strossmayera u Osijeku, P. Preradovića 17, 31400 Đakovo,

Hrvatska, drago. tukara@gmail.com

$U$ drugom dijelu autor donosi primjer prakse pokore u milanskoj Crkvi. Milanski biskup Ambrozije suočavao je samoga sebe sa svojim grijesima, pojedince i cijelu zajednicu. Osobno je bio svjestan potrebe čovjekova obraćenja i Božjega milosräa $i$ nije oklijevao to osobno iskustvo prenijeti čak ni na političke vladare. $U$ tom dijelu ističe se iskustvo grješnosti milanske vjernič̌ke zajednice iz četvrtoga stoljeća te oblik pokore sa svim njezinim dijelovima.

Ključne riječi: crkveni oci, pokora, grijeh, oproštenje, Ambrozije.

\section{Uvod}

Ovaj rad ide unatrag prema ranokršćanskome razdoblju i nije nikakva nostalgija za prošlim vremenima, a nije ni namjera ranokršćansko razdoblje predstaviti kao najisprav- 
nije i najkvalitetnije razdoblje Crkve u odnosu na sakrament ispovijedi. S druge strane ne želi se iskustvo prve Crkve prikazati kao nemoguću misiju koju današnji čovjek ne može ostvariti. Cilj je upoznati dio puta čovjekove grješne i spasenjske povijesti, to je onaj dio puta koji je prvi kršćanin prošao i time otvorio vrata budućnosti. Vraćanje na crkvene oce moglo bi se nazvati memoria storica koja današnju Crkvu potiče na razmišljanje o svojim korijenima kako bi mogla rasti u budućnosti.

Štoviše, ne samo da se želi približiti nauci crkvenih otaca o pokori, nego se želi približiti nauku Isusa Krista. Isus Krist suočio se s problemom ljudskoga grijeha, pravednosti i milosrđa, pa je stoga čitavo svoje poslanje na zemlji posvetio čovjeku grješniku i njegovu obraćenju. U godini Izvanrednoga jubileja milosrda cijela je današnja Crkva pozvana suočiti se s otkrivanjem i približavanjem licu Božjega milosrđa. To lice Božjega milosrđa Crkva je željela od samih svojih početaka otkrivati u sakramentu ispovijedi i nuditi je čovjeku kao sredstvo za postizanje oproštenja i pomirenja s Bogom.

\section{Crkvena pokora i njezini problemi u prvim stoljećima}

Prva kršćanska zajednica svjesna je same sebe kao zajedništva sa svojim članovima i s Bogom i zato je ona mjesto spasenja. Riječ je o zajednici koja ima svete i izabrane članove koji su besplatno dobili oproštenje. Božanski oprost središte je evanđelja i nositi nekome to oproštenje znači ispuniti svoje temeljno poslanje, počevši od Jeruzalema.

Na ponudu takvoga oproštenja čovjek mora uzvratiti jednim novim životom i promjenom svoga mentaliteta. Nakon što je podijeljeno oproštenje po krštenju, kršćanska zajednica stječe iskustvo da ljudsko i božansko zajedništvo može biti narušeno zbog nevjernosti osoba, iako su bliske Kristu. Te osobe, nakon što su se pokajale, mogu ponovno postići oproštenje koje se ne tiče samo obraćenika prvi put nego i članova u zajednici. Sveti Pavao o tome piše: $\gg$ Ako me je tko ražalostio, nije mene ražalostio, već u izvjesnom smislu - da ne pretjerujem - sve vas. Dosta je takvome kazne koju mu je dosudila većina; vi mu, naprotiv, radije oprostite i utješite ga, da ga slučajno ne bi srušila prevelika žalost.« (2 Kor 2, 5-7)

\subsection{ENTUZIJAZAM KRŠĆANSKE ZAJEDNICE}

U apostolsko i postapostolsko vrijeme nije se pravio problem oko davanja oproštenja i ponovnoga vraćanja u puno zajedništvo s kršćanskom zajednicom onoga tko je teško sagriješio. Budući da su u početku zajednice bile malene, pune entuzijazma i snažne unutarnje povezanosti, nevjera je bila rijetka. Cijela se zajednica brinula da se grješnik pokaje: $\gg$ Dok smo na ovomu svijetu, svim se srcem kajmo za grijehe počinjene u tijelu, da nas Gospodin spasi, dok za pokajanje još imamo 
vremena. $\ll^{1} \mathrm{U}$ Apostolskim uputama pronalazimo međusobno prekoravanje i upozorenje vjernika: »Ne izazivaj raskol, već zavađene pomiruj; sudi pravedno, i kada koriš prijestupnike, ne gledaj tko je tko. $\ll^{2}$ A najodgovorniji u zajednici najuključeniji su. Gotovo svi spisi prvoga i drugoga stoljeća govore o opraštanju svih grijeha. Čini se, ipak, da se u to vrijeme dopuštalo ponavljanje pokore, tomu u prilog ide činjenica da iz toga vremena nemamo svjedočanstvo o uskraćivanju ponovnoga oprosta. Na primjer, Tertulijan svjedoči da je Marcion više puta bio isključivan iz zajednice i da se u nju više puta vraćao, sve do konačnoga isključenja. ${ }^{3}$ Ako grješnik nije pokazivao znakove pokajanja, primjenjivalo se isključenje iz zajednice. ${ }^{4} \mathrm{U}$ Klementovoj poslanici Korinćanima izričito se govori o sudu zajednice: $\gg$ Prema tome, tko se među vama osjeća velikodušnim, tko milosrdnim ili punim ljubavi? Takav neka rekne: ako su zbog mene nastale zadjevice, nesloga i razdor, povlačim se, odlazim kamo god hoćete i učinit ću ono što zajednica odredi; samo da Kristovo stado živi u miru s postavljenim prezbiterima. $\ll^{5}$ Sud zajednice vrlo je važan, jer je ona mjesto spasenja, a božanski oprost povezan je s ponovnim oproštenjem ili isključenjem iz Crkve (zajednice). Tako piše Ignacije Antiohijski: »Tko god je Božji i Isusa Krista, taj je s biskupom; i oni koji se, vođeni pokajanjem, vraćaju jedinstvu Crkve bit će Božji jer žive po Isusu Kristu. $\ll^{6}$

$S$ takvim općenitim pristupom pokori u prvom stoljeću dolazi se do jednoga od većih problema u prvoj Crkvi, pitanja pokore, koja od polovice drugoga stoljeća postaje sve zamršenija i tako se razvija do određene stabilnosti u trećem i četvrtom stoljeću, i na Zapadu i na Istoku. U područjima gdje je prisutan latinski jezik od šestoga do sedmoga stoljeća događa se radikalna promjena, a u dvanaestom stoljeću pokora dobiva svoju fizionomiju koja traje do danas. Na Istoku se razvoj pokore događa paralelno s razvojem na Zapadu. Pokora u prvoj Crkvi može se promatrati iz povijesnoga, teološkoga, sociološkoga i liturgijskoga kuta.

${ }^{1}$ APOSTOLSKI OCI, Pseudo-Klementova homilija, VIII, 2., Branko Jozić (prev.), Split, 2011. Istu podršku zajednice pronalazimo i u Ignacija Antiohijskoga u Poslanici koju upućuje Smirnjanima IV, 1.

${ }^{2}$ APOSTOLSKI OCI II, Apostolske upute, 4, 3., Branko Jozić (prev.), Split, 2010. Istu poruku donosi i Barnabina Poslanica, 19, 4; Polikarpova poslanica Filipljanima, 11, 4.

${ }^{3}$ Usp. TERTULIJAN, O zastari heretika, 38, 2-3; PL 2, 51-52.

${ }^{4}$ Usp. APOSTOLSKI OCI II, Apostolske upute, 4,3; I. ANTIOHIJSKI, Poslanica Smirnjanima, 4, 1; 7, 2; Efežanima, 7, 1., Branko Jozić (prev.), Split, 2010.

${ }^{5}$ APOSTOLSKI OCI II, K. RIMSKI, Pismo Korinćanima, LIV, 1 - 2., Branko Jozić (prev.), Split, 2010.

${ }^{6}$ APOSTOLSKI OCI I, I. ANTIOHIJSKI, Poslanica Filadelfijanima, 3, 2., Branko Jozić (prev.), Split, 2010. 
Porastom kršćanske zajednice, kao i ulaskom krštenih osoba u jednu osjetljiviju životnu dob, uočava se manje žara. Uočavaju se slučajevi kada kršćani upadaju u poganske načine života, kršćanska zajednica postaje na neki način razbojnička pećina. Spominju se apostati, izdajice Crkve, osobe zla jezika, osobe koje su bogate, a postale su netrpeljive i ohole. Takvi su napustili istinu i odvojili se od pravednih te su počeli živjeti s poganima. $O$ takvom ponašanju pronalazimo svjedočanstvo kod Polikarpa koji poziva vjernike da se klone svakoga zla: $\gg$ Ako se tko ne uščuva od lakomosti, okaljat će se idolopoklonstvom i ubrojit će se među pogane koji ne znaju suda Gospodnjega ... $\ll^{7}$

\subsection{Ponovni povratak grJešnika u Zajednicu}

U novonastaloj situaciji u zajednici vjernika postavlja se pitanje postoji li mogućnost jedne postkrsne pokore i nakon toga ponovnoga povratka u Crkvu. Evo što je o tome zapisao Hermin Pastir u svojim zapovijedima: »Rekoh: 'Još ću, gospodine, nastaviti s pitanjima. 'Govori', kaza. 'Gospodine, čuo sam od nekih učitelja', nastavih, 'da nema druge pokore osim one kada smo sišli u vodu i dobili oproštenje svojih prijašnjih grijeha.' Reče mi: 'Dobro si shvatio jer je tako. Tko je dobio oproštenje grijeha, ne bi smio više griješiti, nego ostati u čistoći. $\ll^{8}$ Ta se zapovijed odnosi na Rim, ali pronalazimo i drugo svjedočanstvo koje govori o drukčijoj pouci Dionizija Korintskog: $\gg$ Dionizije naređuje da se prihvate obraćenici iz bilo kojega pada, grijeha i krivovjerne zablude. $\ll^{9}$

Nekoliko desetljeća kasnije, početkom trećega stoljeća, Tertulijan, koji je prije davao mogućnost pomirenja, sada oštro kritizira praksu ponovnoga opraštanja grijeha u svom djelu $O$ čistoći. $U$ istim godinama Hipolit Rimski iz istih razloga kori biskupa Kalista. Rigoristička struja u sebi krije mnogo mišljenja, od onih koji ne dopuštaju oprost za sve teške grijehe pa sve do onih koji ne dopuštaju oproštenje samo neke posebne grijehe: preljub, apostazija i slično. Rigoristička struja ne nalazi dokaze u svoju korist, ni biblijske ni teološke, nego je njihova strogost samo psihološke prirode. Radi se samo o pretpostavci da bi oprost mogao otvoriti vrata drugim grijesima, kako i sam Tertulijan, rigorist kaže: »Crkva može opraštati grijehe, ali ja to ne ću raditi radi straha što bi mogli biti počinjeni drugi grijesi. ${ }^{10}$

Premda je rigoristička struja zbog svoje složenosti i motiva odbacivana, ostavila je trag u naučavanju o pokorničkoj praksi koja će se razvijati kasnije u drugom i

\footnotetext{
${ }^{7}$ APOSTOLSKI OCI I, POLIKARP, Poslanica Filipljanima, XI, 2., Branko Jozić (prev.), Split, 2010.

${ }^{8}$ APOSTOLSKI OCI III, Hermin Pastir, zapovijed, 3, 1.

${ }^{9}$ EUZEBIJE CEZAREJSKI, Crkvena povijest, IV, 23, 6, preveo, napisao uvod i bilješke Marijan Mandac, Split, 2004.

${ }^{10}$ TERTULIJAN, O čistoći, 21, 5; PL 2, 1023.
} 
trećem stoljeću. Crkva nastavlja dopuštanje ponovnoga oproštenja, ali prihvaća i novosti koje smo susreli kod Hermina Pastira koji prvi put govori o mogućnosti samo jedne postkrsne pokore u životu, za doista teške grijehe: »Nastavih: ‘Gospodine, ako se žena, pošto bude otpuštena, obrati te se htjedne vratiti mužu, ne će li je primiti? 'Dakako', odvrati, 'ako je muž ne bude primio, griješi i na se navlači veliku krivnju. Naprotiv, treba primiti onoga tko je sagriješio pa se pokajao, ali ne više puta jer za Gospodnje sluge postoji samo jedna pokora.' $\ll{ }^{11}$ Ta novost postala je norma za cijelu antičku Crkvu na Zapadu sve do srednjega vijeka. Neki pape i koncili iz toga vremena propisivali su da se ne smije dopustiti drugo oproštenje grijeha. Sam će sveti Augustin reći da povratnicima nije isključena mogućnost drugoga Božjega oprosta, ali ih Crkva ne će pomiriti sa sobom. ${ }^{12}$

O tom pitanju jedino neslaganje u trećem stoljeću donose Didascalie koje govore o dužnostima biskupa prema grješnicima i nijedna uputa ne govori o samo jednom oproštenju ${ }^{13}$. Krajem drugoga stoljeća penitencijalna disciplina odvija se paralelno s katekumenatom i ona je duga i stroga, nazvana crkvena pokora ili kanonska pokora. Zahtijeva postove, molitve, milostinju i druga mrtvljenja koja su se raspoređivala kroz određeno razdoblje. »Proces ove druge i jedine pokore je strog i kušnja vrlo teška, jer se ne radi samo o nutarnjem činu savjesti, nego se tiče i vanjskog čina koji ukazuje na strogi put pokore «, piše Tertulijan. ${ }^{14} \mathrm{U}$ starini je nazvana eksomológesi ili priznavanje grijeha pred Bogom. Nazivana je i druga pokora s obzirom na to da je krštenje prvo koje je opraštalo grijehe. Ta se pokora promatrala u odnosu prema krštenju. Naime, krštenje je davalo oprost besplatno, ta druga pokora bila je ozbiljna, teška i u suzama ${ }^{15}$. Usporedba $s$ krštenjem učvršćuje ideju jedinstvenosti postkrsne pokore, a o tome sveti Ambrozije kaže da kao što je krštenje jedno, tako je i pokora

${ }^{11}$ APOSTOLSKI OCI, Hermin Pastir, zapovijed, 4, 1, 8., Branko Jozić (prev.), Split, 2010.

${ }^{12}$ Usp. AUGUSTIN, Pismo, 153, 3-8; PL 33, 675-677.

${ }^{13}$ Didascalia degli apostoli, u: DIZIONARIO PATRISTICO E DI ANTICHITÀCRISTIANE, Casale Monferrato, 1994., 948.-949.

${ }^{14}$ TERTULIJAN, O pokori, 7, 9; PL 1, 1247.

${ }^{15}$ Ciprijan nije sumnjao u realnu mogućnost pokore i u njezine milosne plodove jer, prema njemu, bila bi varka poučavati vjernike o pokori, a zatim im nijekati mogućnost ponovnoga zadobivanja zajedništva. Prema njemu to znači da onaj čovjek koji je sagriješio poslije krštenja može biti očišćen od grijeha. Nema smisla da lapsi koji traže izmirenje da ga ne dobiju, a ne dati im mogućnost ponovnoga izmirenja bilo bi protivno dotadašnjoj praksi Crkve. Pokora, prema Ciprijanu, zahtijeva tri trenutka: prvi je eksomológesi ili priznavanje grijeha pred biskupom, ali ponekad i pred prezbiterom i pred đakonom; drugi je zadovoljština, a ona je dragovoljno okajavanje čovjeka pokornika, a njome pokornik svim snagama nastoji zadovoljiti božansku pravednost u omjeru težine počinjenoga grijeha. Za vrijeme zadovoljštine pokornik je privremeno isključen iz euharistijskoga zajedništva. I treći je trenutak povratak u zajedništvo, mir, usp. Scrittori cristiani dell'Africa Romana. CIPRIANO, Lettere 1-50, Introduzione a Cipriano di Cartagine, Roma, 2006., 56. 
jedna koja se ipak čini javno ${ }^{16}$. Kako smo već spomenuli, biblijski argumenti u korist samo jedne pokore ne postoje, ali Augustin tvrdi kako ponavljanje pokore nije moguće iz mudrih i psiholoških motiva. ${ }^{17}$

Velika se važnost daje vanjskim pokorničkim djelima, bilo da se želi postići božanski oprost bilo da se želi pokazati ozbiljnost pokornika. Crkveni službenici nisu podcjenjivali unutarnji vid obraćenja pa su grješniku koji se kaje u teškoj ili smrtnoj opasnosti dopuštali pomirenje samo s obavezom, kada ozdravi, da ispuni javnu pokoru. Naglasak su stavljali na ta djela (zadovoljštinu), kao bitne, i zato su se koristili terminom pokore koji je uključivao u sebi cijeli tijek. Za vrijeme srednjega vijeka, od osmoga do devetoga stoljeća, naglasak se stavljao na ispovijedanje grijeha i to se kazivanje grijeha promatralo već kao jedna zadovoljština. Ona je bila vrjednovana na taj način da je dopuštala mogućnost, naravno, u hitnom slučaju ili u nedostatku svećenika da se ispovijeda pred laikom koji, ipak, nije mogao odriješiti. Promatrano iz teološkoga konteksta, rađa se termin confessio koji zamjenjuje onaj prijašnji penitentia. Uvodi se periodični confessio s posljedicom da se sada zadovoljština ispunjava nakon ispovijedi i odrješenja (pomirenja).

Postojalo je zajedničko uvjerenje da samo Bog daje oprost nakon osobnoga kajanja pa se otvara pitanje koja je onda uloga pomirenja koje daje Crkva. To je pitanje više problem srednjega i modernoga vijeka. Za prve kršćane bio je bitan bilo osobni element bilo čin pomirenja koji je dala Crkva. Lijepo je o tome rekao Leon Veliki: »Darovi božanske dobrote su tako postignuti da se Božji oprost nije mogao postići bez molitava svećenika (biskupa). Posrednik između Boga i ljudi, čovjek Isus Krist je dao poglavarima svoje Crkve moć davanja ispovijedi grešnicima koji se kaju i ponovno da ih vrate natrag, pomoću pomirenja, zajedno sa sakramentima, čim bi bili očišćeni sa spasonosnim kajanjem. Sam Gospodin je stalno prisutan u ovom činu spasenja i nikad se ne miješa u ono što njegovi službenici čine jer on je rekao: 'Evo ja sam s vama u sve dane do svršetka svijeta.'(Mt 28, 20) $\ll^{18}$

Crkveni oci nisu isključivali da grješnik može postići božansko oproštenje, stoga su podržavali da pax ecclesiae ne bi smio manjkati jer samo onaj tko je živi član Crkve može postići spasenje. Crkva je posrednik i mjesto spasenja, zato je njezin oprost bitan. ${ }^{19}$ Sveti Augustin produbljuje naučavanje o pomirenju s jednim primjerom:

\footnotetext{
${ }^{16}$ Usp. AMBROZIJE, O pokori, II, 10, 95., u: OPERA OMNIA DI SANT'AMBROGIO, Roma, 1982.

${ }^{17}$ Usp. AUGUSTIN, Pismo, 153, 7; PL 33, 675-677.

${ }^{18}$ LEON VELIKI, Pismo, 18, 20; PL 54, 1011.

${ }^{19}$ Usp. CIPRIJAN, Pismo, 4, 2., u: Scrittori cristiani dell'Africa Romana. CIPRIANO, Lettere 1-50, Roma, 2006.
} 
Bog sam uskrsava Lazara, ali je Crkva ona koja odmotava zavoje, to jest optužbe od grijeha. ${ }^{20}$

\subsection{VLAST OPRAŠTANJA GRIJEHA}

Govori se o autoritetu Crkve u oproštenju grijeha, a za takav stav pronalazi se utemeljenje u evanđelju gdje se spominje da je Petar stijena i da će se na toj stijeni sagraditi Crkva koju ne će ni vrata paklena nadvladati i da će se dati ključevi Petru pa što god sveže na zemlji, bit će se svezano na nebu i što god odriješi na zemlji, bit će odriješeno na nebu (usp. Mt 18, 18). Iako će kasnije u Crkvi biti upitno na koga se sve to odnosi, samo na Petra ili na njegove nasljednike ili na cijelu Crkvu. Još je sv. Augustin precizno govorio da je ovdje riječ o autoritetu koji pripada cijeloj Crkvi pa kaže da je ključeve kraljevstva nebeskoga za odrješenje i svezivanje grijeha od apostola prvi primio Petar i ne samo on, nego i cijela Crkva. ${ }^{21}$

Vlast opraštanja ipak je prvo pripadala poglavaru zajednice, to jest biskupu, rijetko njegovu delegatu, to jest običnim svećenicima. To je nešto što je bilo neprestano prisutno u prvoj tradiciji. ${ }^{22} \mathrm{Od}$ četvrtoga na peto stoljeće počelo se davati delegaciju svećeniku da može odrješivati od grijeha, sve dok u budućnosti nije postalo normalno da i svećenik odrješuje. S autoritetom biskupa u oproštenju grijeha nije se slagao Tertulijan koji je tu vlast opraštanja pridavao samo Crkvi Duha. ${ }^{23}$

Znamo da su mučenici i confessoresi u prvim trima stoljećima jer su smatrani punima Duha Svetoga obavljali jednu važnu ulogu u opraštanju grijeha. U početku su mogli podjeljivati pax ecclesiae, to jest pomirenje. Na Istoku su ulogu mučenika preuzeli viri Dei i monasi koji su, ako su bili puni Duha Svetoga, mogli primati ispovijedanje grijeha grješnika i dijeliti oproštenje $\mathrm{e}^{24}$.

Crkvena pokora u početku je bila javna u svezi sa zadovoljštinom, to jest pokorničkom praksom, zasigurno ne kao javno ispovijedanje grijeha pred zajednicom, premda se u nekim slučajevima moglo dogoditi i javno ispovijedanje grijeha pred zajednicom. To bi značilo da grješnik nije izričito morao javno iznositi svoje grijehe pred zajednicom, a nakon čega je uslijedila zadovoljština, nego se ovdje pojam jav-

\footnotetext{
${ }^{20}$ Usp. AUGUSTIN, Traktat o Ivanovom evandelju, 22, 7; PL 35, 1577-1578.

${ }^{21}$ Usp. isto, 124, 7; PL 35, 1969-1970; Govor, 99, 9; PL 38, 600.

${ }^{22}$ Usp. Didascalia, II, 10 - 13; https://archive.org/stream/didascaliaetcon00funkgoog\#page/n11/ mode/2up (19. I. 2017); IPPOLITO DI ROMA, La Tradizione apostolica 3, introduzione, traduzione e note a cura di Rachele Tateo, Milano 1995.; LEON VELIKI, Pismo, 18, 2; PL 54, 1011.

${ }^{23}$ Usp. TERTULIJAN, O čistoći, 21, 17; PL 2, 1024.

${ }^{24}$ Usp. L. LIGIER, Il sacramento della penitenza secondo la tradizione orientale, u: La penitenza, Torino, 1968., 151.
} 
ne ispovijedi odnosi na javno ispunjavanje pokorničkih čina. Crkvena pokora bila je javna i zbog teških grijeha koji nisu bili poznati. $U$ tom slučaju bilo je potrebno da grješnik te grijehe ispovijedi pred poglavarom zajednice, privatno ili javno. Taj način bio je poznat već na početku trećega stoljeća. Origen savjetuje da se potraži osobu kojoj bi se ispovjedili vlastiti grijesi kako bi to bilo poput lijeka. ${ }^{25}$ Leon Veliki kori praksu da se javno izrekne grijeh koji je ispovjeđen u tajnosti: »Evo načina suprotnoga od onoga što su ostavili apostoli, način koji se ustalio kako ne treba, za kojeg sam saznao nedavno, te naređujem da se dokine... Naime, treba prestati $\mathrm{s}$ tim da grijesi budu prenešeni (odani ili izdani) samo biskupu u nekom tajnom razgovoru. ${ }^{26}$

Postavlja se pitanje zbog kojih je grijeha bila potrebna ta teška pokora. Kod crkvenih otaca susrećemo gotovo iste termine koji su nam danas poznati: peccata mortalia (capitalia, graviora...) i peccata leviora (venialia-oprostivi, quotidina). Za prve, premda su bili tajni, bila je potrebna crkvena ili kanonska pokora, a za druge bila je dovoljna ona svagdanja pokora koju je svaki dobar kršćanin morao obaviti uz post, molitvu, milostinju. ${ }^{27}$ Zato je načinjen popis grijeha, a pri tome se držalo onoga što kaže Novi Zavjet i Dekalog. Među brojnim popisima grijeha ne postoji u crkvenih otaca ujednačenost. Postoje razlike u popisu. Među glavne grijehe ubrojeni su apostazija, idololatrija, ubojstvo, preljub, blud, krivokletstvo, društvene igre u cirkusu, a isključeni su grijesi počinjeni mišlju.

Pokornička se disciplina nakon Konstantina razvija i mnogo je preciznija u svojim pravilima u odnosu na prethodna razdoblja. Nova politička i socijalna situacija donosi promjene unutar članova kršćanske zajednice.

\subsection{KRIZA POKORNIČKE DISCIPLINE}

Nakon novonastalih promjena, odnosno dobivanja slobode i određenih privilegija prema Milanskom ediktu 313. godine, vjernici postaju ravnodušni prema grijehu i njegovu oproštenju.

${ }^{25}$ Usp. ORIGEN, Homillja na Psalam, 37, II, 6; PG 12, 1386.

${ }^{26}$ LEON VELIKI, Pismo, 168, 2; PL, 54, 1210-1211. Tema o pokori u prvoj Crkvi nije nepoznata crkvenoj javnosti i o njoj se doista mnogo pisalo: E. SPRINGER, Ispovijed i pokora u staro doba, u: Obnovljeni život: časopis za filozofiju i religijske znanosti (1928.)5, 272.-283.; A. MATELJAN, Sakrament pokore u pravoslavlju. Povijesni razvoj i teologija. »Svete tajne ispovijedi/pokajanja «, u: Crkva u svijetu (2007.)2, 285.-304.; Z. LINIĆ, Oblici pokore kroz povijest, u: Bogoslovska smotra (1976.)1-2, 131.-142.; M. SRAKIĆ, A. JARM (ur.), Pomirbeno slavlje, Đakovo, 1978.; P. ŽMIRE, Povijesni prikaz sakramentalne pokore, u: Služba Božja (1975.)4, 268.-277.; F. COURT, Uz povijest prakse pokore i učenja o njoj, u: Sakramenti, Đakovo, 1997.; G. H. JOYCE, Private penance in the Early Church, u: The Journal of Theological Studies (1941.)1, 18.-42.

${ }^{27}$ Usp. AUGUSTIN, Govor, 252, 2, 7; PL 38, 1172-1173. 
$\mathrm{Na}$ isti način iščitavamo zabrinutost prve Crkve: »Toliki traže Isusa, da bi primili materijalna dobra. Jedan obavlja posao, utječe se svećeniku za posredovanje, drugi je ugnjetavan od moćnika, utječe se Crkvi. Drugi opet želi da se zauzima za njega po pitanju pozajmljivanja kredita. Takvim se osobama svaki dan punila Crkva. Jedva da tko traži Isusa radi njega samoga. ${ }^{28}$ Već je Origen u trećem stoljeću oplakivao gorljivost i zabilježio u svome vremenu snažan pad etičkoga kodeksa kršćana: »Jednom bijaše malo vjernika, ali su zaista bili vjernici, jer su slijedili uzak i tijesan put koji je vodio u život. Sada kada smo mnogi, budući da ne mogu biti mnogi izabrani... među mnoštvom, koji su bili poučavani pravom štovanju Boga, malo ih je koji su od Boga izabrani i koji su postigli blaženstvo. $\ll{ }^{29}$ Kako smo vidjeli, kasnije, u vrijeme Augustina stvari su pošle na gore.

Osim političkoga i socijalnoga elementa na vjerski život utječe i uvođenje krštenja djece, što još nije bilo dovoljno razvijeno u kršćanskom nauku i moralu te još nije prokušano kroz katekumenalni put. Nadalje kršćanska zajednica nije više zatvorena skupina u kojoj se može kontrolirati i bratski upozoravati grješnika. Što je veći broj grješnika, to je manja mogućnost njihove kontrole. Sve je manje osoba koje prihvaćaju pokorničku disciplinu u odnosu na one koji prihvaćaju pokoru. Augustin se žali da su mnoga teška i zabranjena ponašanja ušla i među kršćane sve dotle da postaju normalna, a crkveni je autoritet postao tolerantan prema tim ponašanjima: »Tako da radi takvih teških grijeha ne samo da ne smijemo ekskomunicirati jednog laika, nego niti degradirati jednog klerika. $\ll^{30}$

Usprkos promjenama i niskom stupnju kršćanskoga morala, pokornička disciplina nije se prilagođavala nametnutoj situaciji, štoviše, ona je išla prema sve većoj strogoći i unutarnjoj strukturiranosti, a rezultat je toga bio da se pridržavala samo za umiruće. Penitencijalne forme koje su bile stroge, koje su dobro prolazile u vrijeme herojstva i u vrijeme unutarnje povezanosti zajednice, nisu se mogle primijeniti na velike i amorfne mase. Tako su te stroge forme postajale sve beskorisnije. Naime, oni koji su bili opčarani odrješenjem iz prethodnih stoljeća sada su zahtijevali pravne norme kao plod koncila, sinoda ili nekih drugih pisanih oblika. ${ }^{31}$

Bez obzira na sve, pokora je sačuvala svoju unutarnju strukturu, ona je jedna, javna, $s$ isključenjem iz euharistijskoga zajedništva.

\footnotetext{
${ }^{28}$ AUGUSTIN, Traktat o Ivanovom evandelju, 25, 10; PL 35, 1600-1601.

${ }^{29}$ ORIGEN, Homilija o Jeremiji, 4, 3; PG 13, 290.

${ }^{30}$ AUGUSTIN, Enchiridion, 21, 80; 270-271.

${ }^{31} \mathrm{O}$ kanonima ili normama vrijedi pogledati sljedeće: H. DENZINGER, P.HÜNERMANN, Zbirka sažetaka, vjerovanja, definicija i izjava o vjeri i ćudoredu, UPT, Đakovo, 2002.
} 


\subsection{RED POKORE}

Praksa je bila sljedeća: grješnik je tražio pokoru, primio je polaganje ruku i bilo mu je naznačeno što treba činiti i tako ulazi u red pokore, postaje dio skupine koja ima posebno mjesto u Crkvi. Oni koji su bili službeno pritjelovljeni po redu pokore mogli su biti na liturgijskom slavlju, za razliku od katekumena koji su morali izići nakon liturgije riječi, ali su morali biti na koljenima dok su vjernici stajali. Za njih se molilo i na njih su se polagale ruke: »Penitenti su brojni: kada se na njih polože ruke, formira se dugi red... Neki su se grešnici sami od sebe skupili na mjesto predviđeno za grešnike, a neki, koje smo mi isključili, ondje su stajali prisilno. ${ }^{32}$

U Maloj Aziji pokornici su se dijelili u dvije kategorije, za razliku od podjele na Zapadu: flentes (plačući) koji su ostajali vani pred crkvom moleći vjernike da mole za njih, te drugi pravi pravcati pokornici koji su se dijelili u tri podskupine: audientes koji su, kao i katekumeni, mogli sudjelovati u liturgiji riječi i ponovno biti vraćeni natrag, zatim substrati koji su prostrti po zemlji, zatim stantes koji su stajali kao i drugi vjernici. Samo su oni ostajali u crkvi cijelo vrijeme liturgijskoga slavlja, naravno, bez prava na primanje pričesti.

Početkom četvrtoga stoljeća uvodi se kazuistika s obzirom na trajanje pokornikove priprave prema različitim tipovima grijeha. Za teške grijehe priprava je mogla trajati i nekoliko godina. Koncil u Anciri 314. godine nameće doživotnu pokoru za dragovoljno ubojstvo, deset godina za abortus, a za grijehe s područja spolnosti i za idololatriju od dvije do trideset godina, ovisno o okolnostima (kann. 21. i 22.). Bazilije Veliki propisuje deset godina za jedan abortus i dvadeset godina za razbojništvo (ubojstvo). Apostolske konstitucije, nastale u Siriji krajem četvrtoga stoljeća, mnogo su popustljivije. Na Zapadu je u isto vrijeme, u petom i šestom stoljeću, bio rigorizam te se susreću doživotne pokore ${ }^{33}$.

Biskupi su imali veliku slobodu u određivanju trajanja pokore, vodeći računa nadasve o subjektivnim uvjetima grješnika, jer »ako je netko počinio takav krimen da zaslužuje da bude izdvojen od tijela Kristova, u činjenju pokore ne treba se gledati toliko na dužinu vremena koliko na intenzitet njegove žalosti ${ }^{34}$. Zatim imamo drugi zapis: »Što se tiče vrednovanja grijeha, to spada na biskupa. On mora uzeti u obzir optužbe pokornika, ali isto tako njegove suze i kajanje. $\ll^{35}$ Augustin u jednom pismu upućenom Pavlu iz Nole iznosi svoju zabrinutost: »Što reći o problemu kad se mora kazniti ili ne kazniti, budući da u oba slučaja imamo za cilj uživanje u spa-

\footnotetext{
32 AUGUSTIN, Govor, 232, 7, 8; PL 38, 1111.

${ }^{33}$ Usp. I. ANASTASIOU, La disciplina ecclesiastica nella vita del credente, u: Concilium 11 (1975/7).

${ }^{34}$ AUGUSTIN, Enchiridion, 17, 65; PL 40, 262.

${ }^{35}$ PAPA INOCENT, Pismo, 1, 7; PL 20, 465.
} 
šavanju braće? Drugi problem je znati mjeru kažnjavanja, jer treba imati na umu ne samo narav i broj grijeha, nego ipak snagu duše s kojom trpi kaznu ili odbija kaznu, kako bi iz toga izvukao kakvu korist ili barem da ne izvuče iz toga nazadovanje. Toliko je to tajnovito i nejasno... A što se tiče mene, priznajem da mi se događa da svaki dan griješim po tom pitanju i ne znam kada i kako promatrati svetopisamski propis 'Krivce ukori pred svima i ostali imaju strah!' (1Tim 5, 20). $\ll^{36}$

Za umiruće na koncilu u Niceji 325. godine bilo je već ustaljeno: »Što se tiče umirućih, neka se nastavi držati stara regula, to jest: umirući ne smije biti lišen posljednje i neophodne poputbine. Ako bolesnik ozdravi, zauzima mjesto među onima koji imaju udjela u molitvi, nakon što mu je oprošteno i dopušteno zajedništvo (communio). Tako, samo će biskup dati euharistiju, nakon prethodnog i potrebnog preslušanja, onomu koji traži da je primi u smrtnom trenutku.« (kan. 13.) ${ }^{37}$ Ta se regula sporo provodila jer je remetila ne samo praksu u različitim crkvama nego i sam pojam pokore koja je zahtijevala jedno dugo ispaštanje za grijehe, na primjer u rigorističkoj Galiji na snagu je stupila u petom stoljeću, prije svega zaslugom pape Inocenta I. i pape Celestina I.

$\mathrm{Na}$ Zapadu je pokora vjernicima bila posebno teška i neprihvatljiva zbog serije zabrana koje su pogađale one koji su joj se podredili. Takve zabrane ostale su na snazi i nakon što je uslijedilo izmirenje; neke od njih navodimo: nije se mogla preuzeti neka javna građanska služba, služiti vojsku, posvetiti se trgovini, postati klerik i nadasve trajna ustrajnost za oženjene osobe. Te stroge zabrane primjenjivane su posebno u Galiji i Španjolskoj, dok je Leon Veliki bio popustljiviji ${ }^{38}$. Posljedica takve strogoće bila je da gotovo nitko nije prihvaćao kanonsku pokoru osim u posljednjim trenutcima života. Štoviše, koncil u Galiji 506. godine teško je dopuštao pokoru mladim osobama zbog slabosti njihove dobi. Stvarale su se tada zamjene za javnu pokoru, na primjer prihvaćanje monaškoga života koji je smatran ravnim drugom krštenju ili postajanje konvertitom koji provodi privatni asketski život. U obama slučajevima, nakon što su to prihvatili, nije bilo potrebno dugo ispaštanje i odmah su bili pripušteni euharistiji.

Višem kleru, i na Istoku i na Zapadu, od četvrtoga stoljeća nije bila dopuštena pokora, nego degradacija s kojom je odmah išla i duhovna obnova u samoći, obično u samostanima. »Ovo je suprotno praksi Crkve, da bi zaređeni klerici, svećenici i

\footnotetext{
${ }^{36}$ AUGUSTIN, Pismo, 95, 3; PL 33, 353.

${ }^{37}$ w.w.w.documentacatholicaomnia.eu/04z/z_16921769_Mansi_JD_Sacrorum_Conciliorum_

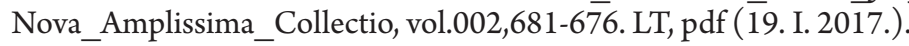

${ }^{38}$ Usp. LEON VELIKI, Pismo, 167, 9-19; PL 54, 1206 -1209.
} 
đakoni, mogli primiti lijek pokore za svoje grijehe polaganjem ruku... Grešni klerici, da bi zaslužili milosrđe Božje, trebaju moliti da se povuku u samoću. ${ }^{39}$

Sada je već javna pokora došla u slijepu ulicu, stoga se od sedmoga stoljeća s lakoćom širi tarifna pokora koju su promicali irski i anglosaksonski monasi. Ona se sastojala od preciznoga ispovijedanja različitih grijeha i točno određene pokore (dnevne, mjesečne, godišnje), snažne nadasve u postu, s mogućnošću zamjene drugim djelima koja su mogle učiniti i neke druge osobe, na primjer monasi. Treba reći da su izdavani mnogi penitencijari koji su sadržavali listu grijeha i za njih predviđenu kaznu koju je morao ispuniti svaki pojedinac. Tako je bilo i na Istoku i na Zapadu. Pokora, koja je već sada postala privatna, mogla se ponoviti za druge grijehe, čime je narušena pretpostavka da se pokora ne može ponoviti i da je jedna. Nadalje je pokora sada regularno povjerena i svećeniku, a ne samo biskupu. Ispovijed je postajala sve učestalija, periodična i obavezna barem jedanput godišnje, kako je propisao Četvrti lateranski koncil 1215. godine.

Mnogo manje znamo kako se razvijala ispovijed na Istoku, ali znamo da je opala zbog inertnosti primjene.

Postoji zanimljiv vid ispovjednoga hoda, a to je da se u vrijeme zadovoljštine koju je morao ispuniti penitent uključila cijela zajednica vjernika bratskim opomenama, savjetima i molitvama. Već je Tertulijan početkom trećega stoljeća tako promatrao ispovijed: »Penitent obično opskrbljuje svoje molitve postovima, savija se do nogu svećenikovih, na koljenima je pred onima koji su Bogu dragi, i moli braću da se zauzmu za postizanje oprosta. $\ll{ }^{40}$ Malo poslije pojačava svoje izlaganje: $\gg$ Ne može se tijelo radovati nesreći jednoga svoga dijela... Gdje su jedan ili dvojica braće, ondje je i Crkva, a Crkva je Krist. Stoga kada širiš ruke prema koljenima braće, grliš Krista, zaklinješ Krista, i slično kada oni prolijevaju suze nad tobom, Krist je onaj koji trpi, Krist je onaj koji se zauzima kod Oca. $\ll^{41}$

Postoje sačuvane molitve koje je zajednica molila, kao i za katekumene, za vrijeme liturgijske skupštine i za pokornike koji su primali polaganje ruku. Konačno izmirenje i pripuštanje liturgijskom slavlju dobivalo se posljednjim polaganjem ruku koje je za pokornika umjesto krštenja jer zajedništvo Duha Svetoga primamo bilo polaganjem ruku bilo krštenjem. ${ }^{42}$

\footnotetext{
${ }^{39}$ LEON VELIKI, Pismo, 167, 2; PL, 1203.

40 TERTULIJAN, O pokori, 9; PL, 2, 1243.

${ }^{41}$ Isto, 10; PL, 2, 1244.

${ }^{42}$ Usp. Didascalia, 2, 41; https://archive.org/stream/didascaliaetcon00funkgoog\#page/n11/mode/ 2up (19. I. 2017.).
} 
Službenik, biskup ili svećenik koji je vršio pomirenje uz polaganje ruku izgovarao je i jednu molitvu, ali nije izgovarao neku formulu odrješenja (ja te odrješujem...), ona je kasnije uvedena. Takav obred bio je poznat u Italiji u četvrtom stoljeću, a odvijao se na Sveti četvrtak. »Što se tiče onih koji čine pokoru bit će pomireni na sveti četvrtak, prema praksi rimske crkve $\ll^{43}$, dok se u Španjolskoj odvija petkom; naravno, u posebnim slučajevima nije bilo potrebno držati se točno određenoga vremena. $\mathrm{Na}$ Istoku je bila praksa pomazivanja pokornika.

\section{Pokora u milanskoj Crkvi}

Uza sve gore spomenute crkvene oce i njihov doprinos posebnu pozornost sada želimo posvetiti svetom Ambroziju, milanskom biskupu koji je dao velik doprinos u pojašnjavanju pojma i sadržaja penitencijalne prakse u svojoj vjerničkoj zajednici. Revni pastir nije štedio ni riječi ni pera za spasenje duša pa je iza sebe ostavio i djelo posvećeno upravo problemu i pitanju pokore. ${ }^{44}$

Dok razvija nauk o pokori, Ambrozije piše i razmišlja biblijski, a to znači da argumente za pokoru izvlači iz biblijskih slika i biblijskih citata. Od doslovnoga shvaćanja biblijskoga teksta dolazi do onoga duhovnoga i alegorijskoga jer mu je taj način najprikladniji za poniranje u misterij koji se krije u tekstu. Evo primjera za spomenuto tumačenje biblijskoga teksta: Čovjek koji je pao u ruke razbojničke i koji je ostavljen na zemlji polumrtav predstavlja lapsa, paloga koji je otpao od Krista po svojim riječima, ali ne i srcem. Samaritanac je zaštitnik naše duše, to je Gospodin, spreman oprostiti onome koji se kaje, spreman poviti rane uljem i vinom; ulje je za ublažavanje, a vino za poticanje na raskajanost. Gostinjac u kojem je nesretnik našao utočište jest zajednica vjernika.

\subsection{POKORA KaO KRJEPOST}

Kada je riječ o krjeposti pokore, ponajprije treba govoriti o prirodi pokore, odnosno o njezinim osobinama.

\subsubsection{Pokora kao intimna žalost duše}

Kako smo rekli, Ambrozije se služi biblijskim slikama i primjerima na temelju kojih izvlači značenje pokore. Kralj David za njega je pravi pokornik, a njegova pokora

${ }^{43}$ INOCENT, Pismo, 25, 7; PL 20, 559.

${ }^{44} \mathrm{Za}$ Ambrozijev nauk o pokori poslužit će nam ponajviše njegovo djelo $O$ pokori u sljedećem izdanju: OPERA OMNIA DI SANT'AMBROGIO, La penitenza, introduzione, traduzione, note e indici di Gabriele Banterle, Roma, 1982. Tijekom rada pozivat ćemo se i na još neka njegova djela $\mathrm{u}$ istom izdanju. 
commemoratio delictorum ${ }^{45}$. Pokora je prisjećanje pogrješaka. To sjećanje nije samo jednostavna spoznaja pogrješaka i nije samo čista promjena razmišljanja, nego je ona poniženje pred Bogom u žaljenju i prolijevanju suza okajnica radi osude, gnušanja i okajavanja vlastitih grijeha. Ti čini u potpunosti opisuju pojam pokore u Ambrozija, ali i u cijeloj Crkvi ondašnjega vremena. Kajanje i okajavanje grijeha uvijek je usmjereno protiv grijeha kao takvoga jer ako je zlo postojalo u prošlosti, ono će biti i dio budućnosti. Stoga ti čini, kajanje i pokajanje, nisu dovoljni, nego se traži, kao dodatna posljedica, nakana ne počiniti ponovno zlo.

Djelo $O$ pokori ${ }^{46}$ koje je Ambrozije napisao bilo je usmjereno protiv onih koji su krivo naučavali pojam pokore (novacijanci), a nakana djela bila je ponuditi ispravan nauk o pokori koja ima svoj tijek i svoje plodove. Pokornik se treba odreći svijeta, odreći se samoga sebe i potpuno se promijeniti. Mora odlučiti da će živjeti novim životom, životom krjeposti koji uključuje bijeg od grješnoga svijeta, kojega se više ne smije sjećati. »Treba se odreći svijeta, čak treba manje pridavati pažnje snu nego što je potrebno, zamijeniti ga s jecanjem, prekinuti ga sa kukanjem, posvetiti ga molitvi. Potrebno je, doista, kao da smo zauvijek umrli našem načinu življenja zemaljskoga života. $\ll{ }^{47} \mathrm{U}$ nastavku izlaganja o značenju pokore i ponašanju pokornika prema grijehu pozvao se na priču o mladiću koji je imao kontakte s bludnicom. Napustio ju je i otišao u stranu zemlju. Vratio se i zaboravio ljubav koju je imao prema njoj, ali ju je susreo. Ona se začudila što joj pri susretu nije ni jednu riječ uputio, pomislila je da ju nije prepoznao. Drugi put kada ga je susrela rekla mu je: »To sam ja!« On je odgovorio: »Ali ja nisam više ja! « Za Ambrozija je taj mladić sebe potpuno oblikovao u nekoga drugoga čovjeka, u neko drugo $j a$.

\subsubsection{Pokora kao nadnaravna krjepost}

Pokora je nadnaravna krjepost koja čovjeka prisiljava da mrzi grijeh ako je on povreda Boga. U ovom slučaju nije riječ o krjeposti pokore kao jednom ulivenom stanju od Boga. Riječ je o krjepostima koje se dobivaju djelima koje pokornik čini. To su njegova dobra djela, hvalevrijedna, spasonosna jer su učinjena na poticaj milosti. Tako se može reći da su nadnaravna. Sama je pokora stoga dobra. ${ }^{48}$ On to potkrjepljuje primjerom svetoga Petra. Petar ne plače nakon prvoga zatajenja jer ga pogled božanski nije dostigao, ne plače ni nakon drugoga zatajenja jer ga božanska milost nije zahvatila. Plače nakon trećega zatajenja jer je Isus, pogledavši ga, ulio u njega

\footnotetext{
${ }^{45}$ AMBROZIJE, Tumačenje Psalma, 37, u: OPERA OMNIA DI SANT' AMBROGIO, Commento a dodici salmi, introduzione, traduzione, note e indici di Luigi Franco Pizzolato, Roma 1980.

${ }^{46}$ Djelo je nastalo više kao traktat između 386. i 390. godine.

${ }^{47}$ AMBROZIJE, O pokori, II, 10, 96.

${ }^{48}$ Usp. isto, II, 11, 98.
} 
onu krjepost po kojoj se plače i mrzi na grijeh. Stoga krjepost pokore dolazi izravno od Boga i zato je nadnaravna.

\subsubsection{Materijalni i formalni objekt pokore}

Nema sumnje da je za Ambrozija subjekt pokore sam čovjek grješnik, a da je osnovni objekt grijeh koji ispovijeda. Materijalni objekt jesu i suze kojima se briše grijeh, kao i besprijekorne radnje kojima se grijeh pokriva kako se ne bi ubrojio.

Otvara se pitanje broja pokora. Ambrozije navodi sljedeće: »Neki su uvjereni da se pokora može više puta činiti. Oni su obuzeti porivima nedostojnim Krista. Da su namjeravali učiniti pokoru čitavim srcem, ne bi vjerovali u mogućnost da ponove pokoru. Samo je jedna pokora i to ona javna. Svaki dan treba okajavati grijehe, ali dok je svagdanja pokora za male grijehe, javna pokora za grijehe teške naravi. « ${ }^{49}$ Ovdje se pojavljuje problem ponavljanja pokore prema Ambrozijevu mišljenju. Čini se da on isključuje tu mogućnost, a ako bi to bilo tako, onda bi bio u proturječju. Zanimljivo je da kaže sljedeće: »Nitko tko se nađe u grijehu ne smije svojatati autoritet sakramenata ili pravo da ih koristi. ${ }^{50}$ On se ovdje poziva na knjigu Postanka 4, 7 gdje Jahve govori Kajinu da iako je ljut na svoga brata, grijeh ipak vreba kao zvijer i da, na neki način, ostane miran i da se odupre toj zvijeri. No on je izišao i ubio brata. Nije mirovao. Poziva se i na Davidov psalam 136 koji govori o nemogućnosti pjevanja Gospodnje pjesme u zemlji tuđinskoj, pa su o vrbe objesili svoje glazbene instrumente. Oni su u mirovanju. Ambrozije to uspoređuje na sljedeći način: »Ako se tijelo opire duhu i ne sluša kormilo duha i njegovu zapovijed, to je strana zemlja koja nije ukroćena radom građana i ne može proizvesti plodove ljubavi, strpljenja i mira. Bolje je onda ostati miran u toj zemlji, ako se ne mogu izvršiti djela pokore, da se ne bi dogodilo nešto što zahtijeva drugu pokoru. Ako je pokora jednom izvršena, ali bez obdržavanja propisanih normi, ne će postići plod koji je očekivan i zapriječit će utok drugoj pokori. $\ll^{51}$

Čini se da on želi samo objediniti praksu koja je bila u ono vrijeme. Ostaje ipak otvoren problem može li se sa stranica koje nam je ostavio taj biskup iščitati je li u četvrtom stoljeću bila praksa samo jedne javne pokore. Ne bi se moglo reći da Ambrozije nije bio svjestan problema pa da je bio u proturječju sa sobom u svezi s tim problemom.

\footnotetext{
${ }^{49}$ Isto, II, 10, 95. Radi važnosti govora o samo jednoj pokori ponovit ćemo istu misao i u bilješci 60 .

${ }^{50}$ Isto, II, 11, 104.

${ }^{51}$ Isto, II, 11, 104.
} 


\subsection{KRJEPOSNI ČINI POKORE}

Kako smo rekli, riječ je o činima koje pokornik obavlja i na taj način čini pokoru krjeposnom. Prva je od tih krjeposti kajanje i gnušanje nad grijehom. Ne nalazimo u njega izričitu definiciju kajanja duše zbog počinjenih grijeha, ali pronalazimo kajanje srca. ${ }^{52}$

U dio pokore pripada i kajanje i skrušenost. U Ambrozija su poznati termini savršeno i nesavršeno kajanje. Prepoznaje one koji se kaju iz ljubavi prema Bogu i one koji se kaju samo zbog straha od budućih muka. ${ }^{53}$ Otvara se nadalje pitanje je li savršeno kajanje formalni uzrok opravdanja i na koji način. Čisti li od grijeha i čini li pravednim neovisno o izlijevanju posvećujuće milosti? $\mathrm{O}$ tome da je savršeno kajanje hvalevrijedno i presudno za opravdanje, ali ne bi bilo formalni uzrok opravdanja, pronalazimo u Ambrozija: »Nije li očito da se Isus ljuti na nas grešnike sa svrhom da se obratimo pomoću napada njegove ljutnje? Njegova ljutnja ne traži osvetu, nego je ona preludij oproštenja. Rekao je: 'Ako se budeš kajao, bit ćeš spašen!' ${ }^{54}$ Stoga očekuje naše jecaje, one zemaljske, kako bi nam oprostio one vječne. Zahtijeva naše plakanje kako bi udijelio milosrđe. U evanđelju čitamo kako je bio ganut vjerom u suzama udovice, pa joj je sina vratio u život. Želi naše kajanje da bismo se utekli njegovoj milosti koja će se čvrsto nastaniti u nama kako ne bismo pali u ropstvo grijeha. Povrijedimo li Boga, on se ljuti sve dok se ne pokajemo. Ponizimo se dakle da bismo stekli uvjete za zasluženo smilovanje, a ne kaznu. ${ }^{55}$

U čine pokore pripada i zadovoljština. Znamo da je zadovoljština učiniti ono što se mora, ona je slobodno preuzimanje kazne, tako da se izravna nepravdu Bogu učinjenu i da se oslobodi vremenite kazne. Sličnu definiciju pronalazimo i u Ambrozija, ali u drugom djelu kada daje definiciju pokore: »Prisjećanje grijeha je cjelovita definicija pokore: jer svatko kažnjava vlastite grijehe iz dana u dan, u razgovorima, kao sa bičem i izriče osudu za počinjenu ljagu. $\ll^{56} \mathrm{Na}$ drugome se mjestu poziva na kralja Davida kojega uzima za primjer skrušenoga čovjeka koji nije oklijevao u

\footnotetext{
${ }^{52}$ Usp. AMBROZIJE, Izlaganje psalma 118, 22, 20. Pokora ili kajanje zbog grijeha poniznost je pred Bogom, kazna, osuda zbog grijeha, udaljavanje od grijeha i grješne želje, vidi u: Tumačenje psalma 37,1 u gore navedenom izdanju. Pokora kralja Davida najbolja je pouka o pokori jer se on kao kralj pokorio i ponizio pred Bogom, duša mu bijaše skrušena, za svoje grijehe platio je cijenom suza; Davidov primjer proglas je propisa pokore... vidi bilješka 56.

${ }^{53}$ Usp. AMBROZIJE, O pokori, II, 9, 86.

${ }^{54} \mathrm{Iz}$ 30, 15: »...mir i obraćenje - spas vam je! « Ambrozije se služio Septuagintom u kojoj stoji citat kako smo ga u tekstu naveli.

${ }^{55}$ AMBROZIJE, O pokori, I, 5, 22.

${ }^{56}$ AMBROZIJE, Izlaganje psalma 37, 2, u gore navedenom izdanju.
} 
skrušenosti svoje duše, a dug svoga grijeha platio je skupom cijenom suza. ${ }^{57}$ Suze, dar, dobra nakana jesu čini koji su slobodni i oni čine da zadovoljština bude čin pravednosti. Onaj tko čini pokoru mora biti spreman trpjeti sramotu i podrediti se uvredama, bez uzrujavanja ako mu se pred oči stavi počinjeni grijeh. Ako je dužan sam sebe optužiti, zašto ne može podnijeti uvrede drugih? Ako nema straha pred drugima biti osramoćen, kako tek manje treba imati straha pred Bogom. Zanimljivo je da Ambrozije rijeku Jordan i milost naziva prvom čašom, dok je druga čaša voda suza i pokora. Te čaše valja izlijevati. Tu vodu treba piti. ${ }^{58}$ Kako je gore rečeno, zadovoljština je izravnavanje nepravde koja je Bogu učinjena, a ona se sastoji od podređivanja, podnošenja sramote, podnošenja uvreda, izlijevanja suza, prisjećanja počinjenih grijeha. Iako nam milanski biskup nije dao definiciju zadovoljštine u pravome smislu, iz njegovih djela možemo izvući pojedine elemente i pojmove kojima se služi današnji katolički nauk o tom pitanju.

\subsection{Potreba Pokore}

\subsubsection{Pokora je potrebna kao sredstvo oslobodenja}

Ambrozije se u svojoj pisanoj ostavštini posebno i rado bavio likom kralja Davida. Gdje god je mogao, predstavljao je svojim vjernicima taj biblijski lik pa tako i u svezi s pokorom. Uzima u usta Gospodinove riječi: »David je prijatelj Božji, prorok, izabrani i od Boga pomazani kralj, svojevoljno se podvrgnuo bičevima grijeha i sramote.« Stoga biskup pita svoga vjernika: »Zašto se ti sramiš svojega grijeha? Koje ćeš opravdanje naći za svoje počinjene grijehe? « Ljudska slabost jednostavno nalaže da se mora činiti pokora. $\gg$ David je pred sebe stavio grižnju savjesti da nikada ne zaboravi počinjene grijehe. David kod sebe proglašava vlastitu nepravdu. David se bavi svojim grijesima, a ne imanjem. David se ne stidi pregledavati svoje grijehe, kako se ne bi stidio pred mojim sudom. A ti si se stidio? Ne bi u miru danas počivao moj siromašni sluga Job, da se nije stidio ona tri kralja, svojih prijatelja. Dakle, budući da se nije sramio povjeriti mi svoje grijehe, ni ja se neću stidjeti i otkriti ti svoje tajne. I kao što se ni David ni Job nisu stidjeli staviti u moje ruke zasluženi sud za počinjene grijehe, povjeriti se mome sudu i mojoj volji, neću se ni ja stidjeti, kada susretnem ove siromašne sluge, nazvati ih svojim prijateljima, jer su tražili moju volju. I baš zato što su prije plakali, sada su utješeni; ti naime, koji si prije uživao, sada

\footnotetext{
${ }^{57}$ Usp. AMBROZIJE, Tumačenje psalma 37, 1; 37, 13; 13, 46.. Istu misao donosi u djelu Tumačenje Lukinog evanđelja, I, 7, u izdanju: OPERA OMNIA DI SANT' AMBROGIO, introduzione, traduzione, note e indici di Giovanni Coppa, Roma 1978., te u Izlaganje psalma 118, 18, 1 u izdanju: OPERA OMNIA DI SANT' AMBROGIO, introduzione, traduzione, note e indici di Luigi Franco Pizzolato, Roma 1987.

${ }^{58}$ Usp. AMBROZIJE, Izlaganje psalma 37, 11, u gore navedenom izdanju.
} 
si podvrgnut kaznama. Nas razdvaja ponor: niti njihova milost može doći do tebe, niti tvoja kazna može doći do njih. $\ll^{\$ 9}$

Iz toga bi se moglo izdvojiti sljedeće: Pokora je potrebna kao jedino sredstvo po kojem se čovjek, nakon krštenja, može osloboditi od grijeha. To je oslobađanje potrebno jer čovjek u pokori spoznaje samoga sebe, priznaje svoju nepravdu, konačno postiže mir i spokoj koji su postigli David i Job, siromašne sluge Božje.

\subsubsection{Pokora kao zapovijed}

Pokora je za Ambrozija zapovijed. Nakon što je poučio da grješnik ne gubi nadu u božansko milosrđe, poziva ga na napuštanje svakoga osjećaja stida i na pokoru prema Davidovu primjeru. To poučavanje o nadi u Božje milosrđe moglo bi se tumačiti kao jedan vid kateheze ili pokorničkoga slavlja koje čovjeku grješniku ulijeva nadu u oslobođenje od grijeha i osjećaja stida. Poučava grješnika da ni s čim ne može opravdati svoja zla djela te da si u tom slučaju osvijesti ljudsku slabu narav koja upućuje na zaključak da su svi ljudi grješni.

Poziva se na svetog Ivana apostola koji je u knjizi Otkrivenja, u svezi s oproštenjem grijeha koji vodi u smrt, napisao biskupu u Pergamu: $\gg$ Ali imam štošta protiv tebe: imaš tamo pristaša nauke 'Balaama', koji je naučio Balaka da zavede 'Izraelove sinove da jedu od mesa žrtvovanog idolima i da bludno griješe'. Tako i ti jednako imaš pristaša nauke nikolaita. Prema tome, obrati se! Ako li ne, doći ću uskoro tebi, i borit ću se protiv njih mačem svojih usta.« $(2,14-16)$. Na to se Ambrozije nadovezuje pa pita pokornika zar ne vidi da je potrebna pokora kako bi postigao oproštenje. ${ }^{60}$ Govoreći o potrebi pokore, govori o zapovijedi ili propisu. Ona je dakle i sredstvo i zapovijed. Ona je sama po sebi potreba i kao takva dovoljna.

\subsection{JAVNA I PRIVATNA POKORA}

Jedno od najotvorenijih pitanja u svezi s disciplinom pokore u četvrtom stoljeću jest njezina privatnost i javnost.

Javna pokora sakramentalna ili nesakramentalna, usmjerena je na opraštanje grijeha ili na izmirenje neke crkvene kazne, a obavljena je prema utvrđenim pravilima ili redu pokore. Ona je javna u svim svojim dijelovima: okajavanje, ispovijedanje, zadovoljština, odrješenje. Ona je isto tako dragovoljna, spontana ili propisana prema nekim kanonskim pravilima.

\footnotetext{
${ }^{59}$ AMBROZIJE, Izlaganje psalma 37, 51., u gore navedenom izdanju. O potrebi pokore govori i u prethodnom 11. ulomku toga poglavlja.

${ }^{60}$ Usp. AMBROZIJE, O pokori, I, 10, 46.
} 
Javna pokora, shvaćana točno kao sakramentalna praksa, svojevoljna ili propisana, posebno kada se tiče javnih glavnih grijeha ili nekih drugih teških grijeha koji su kanonski propisani, imala je u prvim stoljećima dug razvoj. Ne može se iz toga isključiti ni privatna pokora ili polujavna. Sam naziv za javnu pokoru ne nalazimo u patrističkoj literaturi točno naveden, ali se pronalazi opisivanje i primjeri koji su dovoljno jasni za njezino shvaćanje i objašnjenje. Nije potpuno jasno kada točno počinje korištenje nazivom javna pokora, ali se može pretpostaviti da je riječ o početku petoga stoljeća. O javnoj pokori svjedoči svakako milanski biskup Ambrozije: »Neki su uvjereni kako se pokora može obaviti više puta. Oni su obuzeti željama nedostojnim Krista. Da su pozorno obavili pokoru čitavim srcem, ne bi smatrali da je potrebno ponoviti je. Samo je jedno krštenje, samo je jedna pokora, ona koja se čini javno. Svaki se dan treba kajati za grijehe, dok je svagdanje kajanje za male grijehe, javna je za grijehe veće naravi. $\ll{ }^{61} \mathrm{Na}$ drugome mjestu donosi primjer cara Teodozija: »Odložio je sve kraljevske insignije, koje je obično nosio, javno je oplakivao u Crkvi svoj grijeh, kojeg je kao u neznanju počinio, jer je osuđen od drugih, s jaukom i suzama isprosio je oprost. On, car, nije se sramio onog čega su se sramili građani, a to je izvršiti javnu pokoru. Nakon toga nije prošao dan a da nije oplakivao vlastitu pogrešku. $\ll{ }^{62}$ Ovdje je riječ o klasičnom primjeru javne pokore koju je Ambrozije zahtijevao od cara Teodozija zbog počinjenoga zločina u Solunu 390. godine.

\subsubsection{Zahtjevi javne pokore}

Ambrozije objašnjava smisao javne pokore: ona se tiče prije svega grijeha, razaranja grijeha i stoga zahtijeva žalost srca, odluku o nečinjenju više grijeha, izgovaranje grijeha pred svećenikom, okajavanje grijeha pred cijelom Crkvom ponizujući se pred svim vjernicima i ponizno traženje oprosta od bezgraničnoga Božjega milosrđa. »Zar bi možda netko mogao prihvatiti da se stidiš zazvati Boga, kad se ne crveniš moliti jednog čovjeka, i da se sramiš moliti Boga, kojemu kod tebe ništa nije skriveno, dok se ne sramiš ispovjediti svoje grijehe čovjeku, kojemu možeš grijehe sakriti? Možda izbjegavaš svjedoke i osobe koje poznaju tvoju pokorničku molitvu, dok, ako se treba dati zadovoljština čovjeku moraš neophodno uteći se mnogima, udostojati se staviti pod njihov utjecaj, pasti pred njihova koljena, ljubiti im stopala, predstaviti svoju djecu kao one koji još ne znaju što je grijeh kao posrednike oproštenja za njihova oca? U Crkvu se unosi bruka s neispovjedanjem grijeha, budući da smo svi grešni. Po njoj je više zaslužniji onaj koji je ponizniji te je pravedniji onaj

\footnotetext{
${ }^{61}$ Isto, II, 10, 95.

${ }^{62}$ AMBROZIJE, O Teodozijevoj smrti, 34, u: OPERA OMNIA DI SANT’AMBROGIO, Le orazioni funebri, introduzione, traduzione, note e indici di Gabriele Banterle, Roma 1985.
} 
koji uglavnom prezire samoga sebe. $\ll{ }^{63}$ Može se istaknuti kako Ambrozije zahtijeva obavljanje pokore u Crkvi, bez stida pred Bogom i ljudima, navodi što je potrebno učiniti za pokoru te ističe veće dostojanstvo čovjeka koji čini pokoru. Molitve puka i stanje nevinih ne mogu posredovati u oproštenju grijeha ako se čovjek sam ne ponizi.

\subsubsection{Obilježja javne pokore}

Ambrozije se ne zaustavlja samo na tim općenitim crtama pokore, on dodaje i druge.

Prvo, dodaje da je materija javne pokore sastavljena od vrlo teških grijeha. Već smo rekli da je Ambrozije držao da je moguća jedna javna pokora i to za teške grijehe, ali je malo teže saznati o kojim je teškim grijesima riječ. Pokušajmo se ipak približiti nepoznatoj činjenici.

Ambrozije je posegnuo za biblijskim citatom kako bi došao do grijeha: »Što volite: da dođem $k$ vama sa šibom ili s ljubavlju i blagim duhom? (1Kor 4, 21). Pita se što bi moglo značiti 'doći sa šibom'. To označava žestok napad riječima protiv preljuba, osuda rodoskvrnuća, prijekor za oholost onih koji su napuhani, umjesto da zbog toga plaču, to znači konačno presuda izrečena krivcu koji je isključen iz zajednice vjernika i prepušten sili sotone, radi smrti tijela a ne duše. $\ll{ }^{64}$ Ambrozije te grijehe povezuje više s tijelom, a tijelo đavao može uzeti, ali duša je pod Božjom zaštitom, to potvrđuje biblijskim citatom: »Biješ ga šibom, ali mu dušu iz Podzemlja izbavljaš.« (Izr 23, 14) Dakle iz toga se može vidjeti da Ambrozije ipak navodi teške grijehe koje valja ispovijedati i okajavati, koji su teški ili kanonski propisani.

Drugo, Ambrozije govori i o skrivenim grijesima koji su dragovoljna materija javne pokore. Nakon što smo ukazali na mogućnost nabrajanja javnih teških grijeha koji su ujedno i materija javne pokore, ovdje želimo istaknuti one grijehe koje čovjek u sebi krije, drugima su nepoznati, ali čovjek svojom voljom može učiniti da postanu sadržaj javne pokore, pod uvjetom da se dragovoljno podredi javnoj pokori. Evo kako to Ambrozije vidi: »Ako netko, imajući skrivene grijehe, s velikim naporom učini pokoru radi Krista, kako mu može biti uzvraćeno u ovom životu, ako nije ponovno primljen u crkveno zajedništvo? Volio bih da se grešnik nada oproštenju, da ga traži sa suzama, da ga traži sa kukanjem, da ga traži s plačem čitavoga naroda, da pokorno moli za oproštenje. Nakon što mu zajedništvo bude odgođeno drugi i treći puta, neka bude uvjeren da je slabo pokornički molio, neka poveća plač; uzastopno se vraćaj budeći u sebi veće žaljenje, opaši noge svojim rukama, prekri ih

\footnotetext{
${ }^{63}$ AMBROZIJE, O pokori, II, 10, 91.

${ }^{64}$ Isto, I, 13, 60.
} 
poljupcima, peri ih sa svojim suzama (...) kako bi Krist mogao reći da su mu mnogi grijesi oprošteni jer je mnogo ljubio (Lk 7, 47). $\ll^{65}$ Ovdje Ambrozije poziva vjernika da javno očituje i ispovjedi svoj tajni grijeh pred zajednicom, da se za njega iskreno kaje i čini pokoru kako bi mogao ponovno biti primljen u zajednicu i kako bi mu Krist mogao uzvratiti.

Treće, u Ambrozija pronalazimo odrješenje u javnoj pokori koje se ne daje odmah nakon ispovijedi grijeha, nego je prepušteno prosudbi svećenika i podijeljeno kada su uvjeti pokornika i njegove zadovoljštine manje-više ispunjeni. Iz prethodnoga citata vidjeli smo da je odrješenje odgađano dva do tri puta.

Četvrto, javna pokora, osim javne prakse koju ističu zajedno sa svetim Ambrozijem i prethodni crkveni oci, sa sobom nosi: traženje ispovijedi, ispovijedanje grijeha, prihvaćanje pokore, čin pokore (javno oplakivati u Crkvi grijehe, plačući, u suzama moliti, Boga pokorno moliti, ishoditi pomoć svetoga puka, post, molitva, milostinja). ${ }^{66}$ Uzima za primjer osobe koje misle da je prava ispovijed ona koja je spojiva sa željom za postizanjem ugleda i časti, da je spojiva s blaženim životom koji se vodi u gozbama i zabavama svoga tijela. Drugim riječima, onaj koji je obavio pravu ispovijed treba zaboraviti druženje sa svijetom i s onim što svijet nudi. Družeći se sa svijetom, ne može se sačuvati nevinost. ${ }^{67}$

Peto, Ambrozije s velikim zanimanjem promatra vlastitost javne pokore, a ona je jedinstvenost. Kao što smo već spomenuli, ${ }^{68}$ on kaže da postoji samo jedno krštenje pa tako postoji samo jedna pokora. To nije samo nauk koji pronalazimo u milanskoga biskupa, nego su tako smatrali oci prije njega. Takvo je shvaćanje već postalo tradicija u prvih kršćana. O jedinstvenosti javne pokore govore Herma Pastir, Tertulijan, Origen, Klement Aleksandrijski i drugi kasniji kršćanski pisci kao što je Augustin koji, ipak, toj javnoj pokori stavlja nasuprot onu pokoru koja se može ponoviti, koju ćemo kasnije nazvati privatna ispovijed. ${ }^{69}$

Nailazi se na veliku poteškoću kada je u pitanju jedinstvenost javne pokore jer je njezin domet samo je jedanput obaviti, stoga se postavlja pitanje o onima koji su ponovno pali u grijeh za koji je predviđena pokora. Dosta je teško saznati na temelju zapisanoga je li Ambrozije davao mogućnost druge pokore za one koji su pali ponovno u grijeh. Na temelju njegove pastirske skrbi i općenito brige za čovjeka moglo bi se pozitivno odgovoriti na to pitanje. Na kraju krajeva, on ne pravi neku

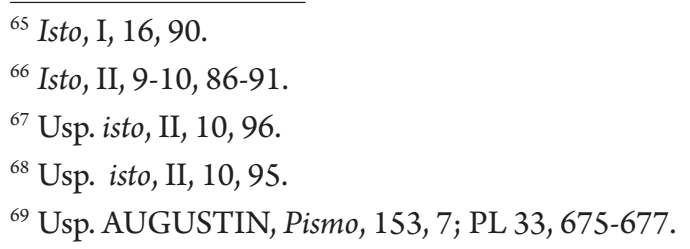


razliku među grijesima i grješnicima, svima obećava oproštenje, sve želi pomiriti s Bogom jer to baš hoće i Bog: »Dakle, iz učenja Gospodinova jasno je propisano da se grešnicima s vrlo teškim grijesima treba povratiti milost nebeskog sakramenta, samo ako sa citavim srcem i s otvorenim ispovijedanjem ispovjede svoje grijehe. $\ll^{70}$ Očito je ovdje riječ o oproštenju svih grijeha i oproštenju za sve grješnike.

Šesto, želimo u Ambrozija promatrati red pokore i vrijeme kada se događa odrješenje od grijeha. Poznato je da je red pokore uključivao pokornike koji su plakali, slušali, prostirali se, i one koji su stajali. To je bila praksa na Istoku, dok na Zapadu nije još bila prisutna. Za takvu praksu možemo naći potvrdu u njegovu tumačenju biblijskoga teksta koji se odnosi na Lazara. Gospodinove riječi upućene sestrama o tome gdje su Lazara stavile, Ambrozije tumači na ovaj način: među kojim se grješnicima nalazi Lazar, u kojoj je kategoriji, među onima koji plaču, slušaju, koji su prostrti ili među stajaćima.

Što se tiče vremena u kojem se događa odrješenje milanska Crkva izdvaja se od redovite prakse drugih Crkava, među kojima je i rimska Crkva koja ga dijeli na Veliku subotu. Milanska Crkva dijeli ga na Veliki četvrtak, kako kaže Ambrozije, na dan kada je Gospodin sam sebe predao, na dan kada je pokora u Crkvi raširena. Na drugom mjestu kaže: »Naime svaki puta kada pijemo Gospodinovu krv, naviještamo smrt Gospodinovu. Kako se samo jednom žrtvovao za sve nas, tako svaki puta kada nam se opraštaju grijesi, primamo sakramenat njegova tijela, jer po njegovoj krvi grijesi su nam otpušteni. $\ll^{71}$

\subsection{NARAV I PONAVLJANJE PRIVATNE POKORE}

Privatna se pokora ne razlikuje od javne po apsolutnoj tajnosti njezinih čina jer oni u privatnoj mogu biti djelomično tajni, dok su u javnoj javni. Penitent u privatnoj pokori nije pošteđen podređivanja propisanom redu i obavljanja brojnih i veoma teških zadanih okajničkih djela. Nije isključena ni jedna zadovoljština jer svaki grijeh zahtijeva okajavanje pred Bogom. Privatna je pokora, reći ćemo, kraća i ublaženija ako ublažava i sužava u posebnim slučajevima, za neke grješnike, formalnost kanonske pokore.

Tako ublažena i sužena pokora nazvana je privatna pokora te je našla svoje utemeljenje u Isusovoj riječi: »pođi te ga ukori nasamo« $($ Mt 18, 15), u crkvenih otaca koji zajedno s pravednošću preporučuju oproštenje, zatim u pokorničkoj praksi prvih stoljeća. Čini se da je ta pokora bila blaža, manje stroga i ozbiljnija od pokorničke prakse koja će kasnije doći. Evo kako Ambrozijev biograf opisuje njegove kre-

\footnotetext{
${ }^{70}$ AMBROZIJE, O pokori, I, 3, 19.

${ }^{71}$ Isto, II, 3, 18.
} 
posti i karakter, pa i praksu pokore: $\gg$ Radovao se sa radosnima, plakao je s onima koji su plakali: naime, svaki puta kada mu je netko ispovijedao svoje grijehe kako bi primio pokoru, plakao je do te mjere da je onoga koji se sagriješio natjerao na plač, pa se činilo da je on sam upao u taj grijeh zajedno s onim koji je doista počinio grijeh. O grijesima koji su mu ispovijedani, o njima ni s kim nije govorio osim ako ne s Gospodinom, kod kojega se zauzimao za grešnika. Tako je ostavio dobar primjer biskupima nasljednicima, kako bi bili posrednici kod Boga a ne tužitelji kod ljudi. $\ll^{72} \mathrm{Ne}$ može se ovdje ne odnositi na privatnu pokoru.

I privatna pokora ima obilježja suđenja. Ona se promatrala kao jedan sud, a Ambrozije je kao sudac koji sluša grijehe pokornika, osuđuje grješnost, naređuje način okajavanja, zauzima se kod Boga kako bi ga odriješio. To se odrješenje odnosi na manje teške grijehe i na male grijehe, ali ne isključuje i one u smrtnoj situaciji ili nekoj posebnoj situaciji. Za razliku od javne pokore koja je jedna i neponovljiva kada se grješnik svaki put prostire pred svećenikom, osuđuje svoje grijehe, prima pokoru.

Ponavljano odrješenje koje pripisujemo privatnoj pokori očituje pojam ispovijedi kao institucije, što i sam Ambrozije donosi, i pokazuje bezgranično milosrđe Boga i Crkve, koja jednom neponovljivom krštenju dodaje privatnu pokoru, koja se može ponoviti, s pomoću koje se čovjek može neprestano čistiti od svojih grijeha i tako postati dostojan uzvišene slave, života vječnoga.

\section{Zaključak}

Po svojoj je prirodi ustanova pokore složena jer uključuje mnogo različitih elemenata: osobnih, unutarnjih ili vanjskih, zajednicu, milosrđe i Božju dobrotu. Kulturološka i teološka osjetljivost vremena u kojem se odvija pokora utječe na stavljanje naglaska na pojedine njezine dijelove. Tako se $u$ antičko vrijeme više stavljao naglasak na zadovoljštinu i ona je pripadala samo hrabrima; dok moderni svijet stavlja naglasak na unutarnji čin pokore i na Božju dobrotu, što je stvorilo od pokore jednu rutinu. Sve to govori da je složenost pokore potrebno promatrati iz svih gledišta koja omogućuju napredne znanosti. U povijesti se nastojalo, bilo iz teoloških bilo iz apologetskih razloga, skupiti mnoge elemente kako bi se stvorila manje-više jedinstvena slika pokore. Prva vremena Crkve, zavisno od mjesta do mjesta, ukazuju na tolike različitosti u razvoju pokore koje nije lako svesti na jedan oblik. U svezi s pokorom u prvim trima stoljećima Crkve čini se da postoje mnogo veće različitosti nego što se mislilo, a one će se u kasnijim stoljećima smanjivati, vjerojatno zbog utjecaja koncilskih i drugih propisa.

${ }_{72}$ PAOLINO, Vita di Ambrogio, 39, Traduzione introduzione e note a cura di Manlio Simonetti, Roma, 1977. 
Zaključno bi se moglo reći da se pastoralna praksa prve Crkve što se tiče sakramenta pokore odvijala u sljedećim vidovima: uvijek je vladalo razumijevanje za ljudske slabosti i poticalo se nadu i vjeru u Božje milosrđe, ali je istovremeno bila prisutna svijest da se ne smije oklijevati u prosuđivanju i osudi grijeha s pozivom na popravljanje i obraćenje. 


\title{
PENANCE IN THE EARLY CHRISTIAN PERIOD WITH SPECIAL REFERENCE TO SAINT AMBROSE
}

\author{
Drago TUKARA*
}

Summary: The author divided the article in two parts. The first part discusses the theme of penance in its historical development from the very beginning of the Church until the end of the fifth century. The consideration includes a series of social events on the stage of that time, that would affect the anthropological and theological aspect of penance. The awareness of the presence of sin in the life of believers after baptism will increasingly encourage the Church to seek solutions to this problem. The Church sees the answer to the question of the $\gg n e w l y$-created « sin in the closer cooperation with the Holy Scripture and tradition. They are the true source of God's mercy, forgiveness and salvation that are gained through the sacrament of penance, which is needed and mandatory.

In the second part, the author gives an example of the practice of penance in the Church of Milan. Bishop Ambrose of Milan had faced himself with his sins, individuals, and the entire community. He was personally aware of man's need of repentance and God's mercy and he did not hesitate to convey this personal experience even to the political rulers. This part emphasizes the experience of sinfulness of the Milan community of believers from the fourth century, and the form of confession with all its parts.

Keywords: Church Fathers, penance, sin, forgiveness, Ambrose.

* Asst. Prof. Drago Tukara, Ph. D., Catholic Faculty of Theology in Đakovo, J. J. Strossmayer University of Osijek, P. Preradovića 17, 31400 Đakovo, Croatia, drago.tukara@gmail.com 